\title{
Off-season Flower Induction of Longan with Potassium Chlorate, Sodium Chlorite, and Sodium Hypochlorite
}

\author{
Tracie K. Matsumoto ${ }^{1,4}$, Mike A. Nagao ${ }^{2}$, and Bruce Mackey ${ }^{3}$
}

AdDITIONAL INDEX wORDs. Dimocarpus longan, bleach, subtropical fruit tree, dragon eye, Sapindaceae

SuMMARY. Flower induction of longan (Dimocarpus longan) with potassium chlorate has improved the availability of longan fruit, but potassium chlorate is potentially explosive and often difficult to purchase, transport, and store. Previous reports suggested that hypochlorite enhances natural longan flower induction. This study is the first to demonstrate that chlorite- and hypochlorite- (bleach) induced off-season longan flowering is similar to chlorate-treated trees. Hypochlorite induction of flowering with bleach was likely the result of chlorate in the bleach solution. Chlorate was present in the leachate from potted longan trees treated with bleach and was detected in bleach before soil application. The quantity of chlorate found in bleach induced flowering to the same or greater extent as equivalent quantities of potassium chlorate, suggesting chlorate is an a.i. responsible for longan flowering.

L ongan is in the Sapindaceae family along with its other better known relatives, lychee (Litchi chinensis) and rambutan (Nephelium lappaceum). Commonly referred to as dragon eye, the longan fruit is smooth, round, and yellowish brown at harvest with a translucent and crispy edible aril surrounding a round, brown-black seed. Although usually consumed fresh, the dried longan fruit is used for medicinal purposes or as a tea during special occasions (Zee et al., 1998).

Longan trees are commonly grown in many subtropical and tropical countries with the majority of the production in Thailand, Taiwan, China, and Australia (Menzel et al., 2002). In the United States, major

Mention of trademark, proprietary product, or vendor does not constitute a guarantee or warranty of the product by the U.S. Department of Agriculture and does not imply its approval to the exclusion of other products or vendors that also may be suitable.

We thank Richard and Jenny Johnson of Onomea Orchards for kindly donating use of the longan trees, Tsuyoshi Tsumura for his excellent technical assistance, and Dr. Francis Zee for technical discussion and critical review of the manuscript.

${ }^{1}$ USDA, ARS, Pacific Basin Agricultural Research Center, Tropical Plant Genetic Resource Management Unit, P.O. Box 4487, Hilo, HI 96720

${ }^{2}$ Department of Tropical Plant and Soil Sciences, College of Tropical Agriculture and Human Resources, University of Hawaii at Manoa, Komohana Agricultural Complex, 875 Komohana Street, Hilo, HI 96720

${ }^{3}$ USDA, ARS, Pacific West Area, 800 Buchanan Street, Albany, CA 94710

${ }^{4}$ Corresponding author. E-mail: tmatsumoto@ pbarc.ars.usda.gov. production occurs in Florida, Hawaii, and California. In 1998, the United States produced 1.4 million $\mathrm{lb}$ of longan with an estimated value of $\$ 2.8$ million (Mossler and Nesheim, 2002). In Hawaii, production was valued at $\$ 438,000$ for $142,000 \mathrm{lb}$ of longan sold in 2005. Future longan production is expected to increase with current fruit production based on only $\approx 47 \%$ of the total acreage planted in longan trees [U.S. Department of Agriculture (USDA), National Agricultural Statistics Service and Hawaii Department of Agriculture, 2006].

Floral initiation in longan is dependent on cool and dry environmental conditions with flowering occurring during March to May in Hawaii (Sabhadrabandhu and Yapwattanaphun, 2001; Zee et al., 1998). Inconsistent floral induction and alternate bearing in longan production has been alleviated by the discovery of potassium chlorate $\left(\mathrm{KClO}_{3}\right)$ to induce off-season flowers and fruits worldwide (Choo, 2000; Manochai et al., 2005; Nagao and Ho-a, 2000; Sabhadrabandhu and Yapwattanaphun, 2001; Yen et al., 2001). Application of $\mathrm{KClO}_{3}$ as a soil drench (10\% to $20 \%$ chlorate solution), broadcast under the canopy (200 to $400 \mathrm{~g}$ /tree), foliar spray (1 to $2 \mathrm{~g} \cdot \mathrm{L}^{-1}$ ), or branch or stem injection $\left(0.05\right.$ to $0.25 \mathrm{~g} \cdot \mathrm{cm}^{-1}$ branch) is effective for promoting flowering (Manochai et al., 2005; Yen, 2000; Yen et al., 2001). For optimal flowering, $\mathrm{KClO}_{3}$ should be applied to trees with mature leaf flushes $\approx 40$ to $45 \mathrm{~d}$ old (Manochai et al., 2005). Although $\mathrm{KClO}_{3}$ induces flowering regardless of the genotype, the flowering response of each cultivar may vary with $100 \%$ flowering observed in 'Si-Chompoo' after application of $1.0 \mathrm{~g} \cdot \mathrm{m}^{-2}$, whereas 'EDaw' required $8.0 \mathrm{~g} \cdot \mathrm{m}^{-2}$ (Manochai et al., 2005). Fruits obtained from $\mathrm{KClO}_{3}$-treated plants do not contain chlorate, chlorite, or hypochlorite residues in the aril, and the size, weight, exocarp color, fruit pole strength, fruit volume, total soluble sugars, and sulfur dioxide residues from postharvest treatment are unaffected (Kanaree and Pankasemsuk, 2005a, 2005b).

Originally discovered as the a.i. in fireworks gunpowder, $\mathrm{KClO}_{3}$ is a strong oxidizing agent responsible for the explosive nature of fireworks (Yen, 2000; Yen et al., 2001). Potassium chlorate is an extremely useful

\begin{tabular}{llll}
\hline $\begin{array}{l}\text { Units } \\
\text { To convert U.S. to SI, } \\
\text { multiply by }\end{array}$ & U.S. unit & SI unit & $\begin{array}{l}\text { To convert SI to U.S., } \\
\text { multiply by }\end{array}$ \\
\hline 29.5735 & $\mathrm{fl} \mathrm{oz}$ & $\mathrm{mL}$ & 0.0338 \\
318.3268 & $\mathrm{fl} \mathrm{oz} / \mathrm{ft}^{2}$ & $\mathrm{~mL} \cdot \mathrm{m}^{-2}$ & 0.0031 \\
0.3048 & $\mathrm{ft}$ & $\mathrm{m}$ & 3.2808 \\
0.0929 & $\mathrm{ft}^{2}$ & $\mathrm{~m}^{2}$ & 10.7639 \\
3.7854 & $\mathrm{gal}$ & $\mathrm{L}$ & 0.2642 \\
2.5400 & inch $(\mathrm{es})$ & $\mathrm{cm}$ & 0.3937 \\
0.4536 & $\mathrm{lb}$ & $\mathrm{kg}$ & 2.2046 \\
1 & micron & $\mu \mathrm{m}$ & 1 \\
28.3495 & $\mathrm{oz}$ & $\mathrm{g}$ & 0.0353 \\
305.1517 & $\mathrm{oz} / \mathrm{ft}^{2}$ & $\mathrm{~g} \cdot \mathrm{m}^{-2}$ & 0.0033 \\
7.4892 & $\mathrm{oz} / \mathrm{gal}$ & $\mathrm{g} \cdot \mathrm{L}^{-1}$ & 0.1335 \\
11.1612 & $\mathrm{oz} / \mathrm{inch}$ & $\mathrm{g} \cdot \mathrm{cm}^{-1}$ & 0.0896 \\
1 & $\mathrm{ppb}$ & $\mu \mathrm{g} \cdot \mathrm{L}^{-1}$ & 1 \\
1 & $\mathrm{ppm}$ & $\mathrm{mg} \cdot \mathrm{L}^{-1}$ & 1 \\
14.7868 & $\mathrm{tablespoon}$ & $\mathrm{cm}$ & 0.0676 \\
$\left({ }^{\circ} \mathrm{F}-32\right) \div 1.8$ & ${ }^{\circ} \mathrm{F}$ & ${ }^{\circ} \mathrm{C}$ & $\left(1.8 \times{ }^{\circ} \mathrm{C}\right)+32$
\end{tabular}


tool to effectively plan flowering and fruiting of longan trees for market. However, the dangers associated with large quantities of this chemical make it difficult to obtain and store; a mixture of $\mathrm{KClO}_{3}$ and sulfur was responsible for an explosion at a longan processing plant in Chiang Mai, Thailand, killing 35 workers and injuring over 100. Lack of personal protection equipment during prolonged use of $\mathrm{KClO}_{3}$ by Thai longan workers resulted in increased levels of anemia, thrombocytopenia, high serum creatinine, and methemoglobinemia, which are hypothesized to be related to $\mathrm{KClO}_{3}$ toxicity (Wiwatanadate et al., 2001).

Sodium hypochlorite $(\mathrm{NaOCl})$ is the a.i. in bleach and has been shown to increase flowering of 'Do' longan trees $53.7 \%$ flower emergence in untreated trees versus $96.2 \%$ flower emergence in treated trees) (Sritontip et al., 2005a). However, it is not clear if $\mathrm{NaOCl}$ can induce off-season flowering because soil drenches with $\mathrm{NaOCl}$ at $50 \mathrm{~mL} \cdot \mathrm{m}^{-2}$ of canopy produced only $5 \%$ flower emergence compared with $\mathrm{KClO}_{3} 5 \mathrm{~g} \cdot \mathrm{m}^{-2}$ canopy, which produced $75 \%$ of flower emergence (Sritontip et al., 2005b). The objective of this experiment was to determine if $\mathrm{NaOCl}$ can be used as an alternative to potassium chlorate for off-season longan flower induction in Hawaii.

\section{Materials and methods}

Expт. 1. Four-year-old 'Egami' and 'Biew Kiew' longan trees on the University of Hawaii, Waiakea Agriculture Research Station (WRS), were used for this study. The soil consisted of an extremely stony Papai muck with organic soils formed over mostly fragmented a'a lava. On 15 Sept. 2004 , the longan trees were untreated or treated with $300 \mathrm{~g} /$ tree $\mathrm{KClO}_{3}$ or $300 \mathrm{~g} /$ tree $\mathrm{NaClO}_{2}$ applied as a granular broadcast under the tree canopy or $2 \mathrm{gal} /$ tree liquid $\mathrm{NaOCl}$ bleach solution [397 mL $(397 \mathrm{~g}) \mathrm{NaOCl}$ a.i.] or $2 \mathrm{gal} /$ tree bleach plus $0.5 \mathrm{~g}$ copper chloride $\left(\mathrm{CuCl}_{2}\right)$ applied as a soil drench under the tree canopy. The experiment was a completely randomized design with three trees per treatment. Two 'Egami' trees and one 'Biew Kiew' tree were randomly assigned to each treatment. On 10 Dec. 2004, flowering stopped and percent flowering was calculated by recording the number of flowering terminals divided by the total number of terminals in the tree canopy.

ExPT. 2. The experiment was conducted in a well-drained silty clay loam soil in Onomea, Hawaii, where mean maximum and minimum temperatures were 26 and $19^{\circ} \mathrm{C}$, respectively, and annual rainfall was $\approx 3781$ $\mathrm{mm}$. The experiment was repeated twice (18 May 2005 and 16 Sept. 2005). Three-year-old 'Biew Kiew' trees were selected for uniformity in vegetative flushing, and each treatment was randomly assigned to three trees (May application) or five trees (September application). Plants were treated as follows: no treatment control; $300 \mathrm{~g} /$ tree (May) or $250 \mathrm{~g} /$ tree $\mathrm{KClO}_{3}$ (September) broadcasted under the canopy; $45 \mathrm{~g} /$ tree (May) or $50 \mathrm{~g} /$ tree $\mathrm{KClO}_{3}$ (September) broadcasted under the canopy; and 2 gal bleach (May and September) applied as a soil drench under the tree canopy. After the $\mathrm{KClO}_{3}$ applications, 2 gal of water was applied on the soil surface. Flowering was monitored biweekly by counting the number of flowering and nonflowering terminals on two sides (north and south) of the tree and determining the percentage of flowering terminals.

Statistical anALYSIs. SAS (SAS Institute, Cary, N.C.) PROC GLIMMIX was used for a generalized linear models approach with a logit link for the binomial responses (Littell et al., 2002). Treatment means were tested for a decrease from the $\mathrm{KClO}_{3}$ standard using Dunnett's adjustment for multiplicity. In Expt. 2, test of effects slices were used to compare the north and south tree faces within treatments.

Chlorate analysis. Two-yearold 'Biew Kiew' plants were grown at the USDA, Agricultural Research Service, Pacific Basin Agricultural Research Center, Tropical Plant Genetic Resource Management Unit at WRS in 15-gal pots containing a $1: 1: 1$ (by volume) mixture of soil, composted macadamia husks, and volcanic cinder. Plants were kept in a covered greenhouse and fertilized bimonthly with 1 tablespoon of $16 \mathrm{~N}-7 \mathrm{P}-13.3 \mathrm{~K}$ plus micronutrients and monthly with 1 tablespoon/L of $30 \mathrm{~N}-4.4 \mathrm{P}-8.4 \mathrm{~K}$ foliar fertilizer. Plants were watered three times weekly with $\approx 19 \mathrm{~L}$ water.
On 10 Aug. 2005, three potted trees were irrigated with either 1) 0.5 $\mathrm{L}$ water, 2) $0.5 \mathrm{~L}$ bleach $(26.25 \mathrm{~g}$ $\mathrm{NaOCl}$ ), or 3) $26.25 \mathrm{~g} \mathrm{KClO}_{3}$ granular broadcast with $0.5 \mathrm{~L}$ water. Plants were irrigated to maintain adequate soil moisture for growth but avoiding excess water leaching through the pot. One month after application, the pots were uniformly irrigated with $\approx 10 \mathrm{~L}$ of water. Gravitation water from the soil was collected and volume recorded. The water samples were filtered with a $0.2-\mu \mathrm{m}$ filter to remove soil particles and sent to NovaChem Laboratories Inc. (Oxford, Ohio) and analyzed for chlorate and chlorite according to the National Environmental Laboratory Accreditation Conference standard using ion chromatography (Environmental Protection Agency Method $300.1)$. Commercial bleach $(5.25 \%$ $\mathrm{NaOCl}$ ) samples were diluted 1:10 with distilled, deionized water and also analyzed for chlorate (NovaChem Laboratories).

SoIL ANALYsis. Soil samples from three 'Biew Kiew' trees treated with 2 gal bleach and three untreated trees grown at the Onomea site were analyzed for salinity and sodium $\left(\mathrm{Na}^{+}\right)$ content. Fourteen weeks and 1 year after treatment, four $16-\mathrm{cm}$ core samples were taken $50 \mathrm{~cm}$ from the trunk. Subsamples from each tree were pooled and sent to the University of Hawaii, College of Tropical Agriculture and Human Resources, Agricultural Diagnostic Service Center, Honolulu.

\section{Results and discussion}

Expт. 1. Flowering of trees at the WRS treated with $\mathrm{KClO}_{3}, \mathrm{NaClO}_{2}$, bleach, and bleach plus $\mathrm{CuCl}_{2}$ began 5 weeks (22 Oct. 2004) after treatment. By 12 weeks after treatment, trees stopped production of panicles and the number of flowering terminals was determined. Nontreated control trees did not flower and $\mathrm{KClO}_{3}, \mathrm{NaClO}_{2}$, bleach, and bleach plus $\mathrm{CuCl}_{2}$-treated trees exhibited 97.8\% (484 flowering/495 total terminals), $91.8 \%$ (462 flowering/503 total terminals), $84.7 \%$ (326 flowering/385 total terminals), and $96.9 \%$ (493 flowering/509 total terminals) flowering, respectively. The means for each treatment were not significantly less than the $\mathrm{KClO}_{3}$ treatment 
$(P>0.27)$ for $\mathrm{NaClO}_{2}$, bleach $(P>$ $0.18)$, and bleach plus $\mathrm{CuCl}_{2}(P>$ $0.43)$ as analyzed by SAS PROC GLIMMIX using Dunnett's adjustment for multiplicity. This demonstrates that chlorate, chlorite, and hypochlorite can effectively induce off-season flowering of longan.

Investigation into the mechanism of chlorate toxicity by Aberg suggested that the chlorate toxicity is incited by reduction of chlorate to chlorite and hypochlorite by nitrate reductase (reviewed by LaBrie et al., 1991). As predicted by Aberg, the majority of plant nitrate reductase enzymes reduce chlorate to the toxic chlorite. Chlorate was used extensively in the past as an herbicide to control problematic weeds such as bindweed (Latshaw and Zahnley, 1927; Loomis et al., 1933; Neller, 1930) and is the a.i. in many herbicides used today (Bennett and Shaw, 2000). Chlorate has also been useful in the isolation of mutants with reduced nitrate uptake or impaired nitrate reductase activity (Crawford and Forde, 2002; Crawford and Glass, 1998; LaBrie et al., 1991; Meyer and Stitt, 2001). Nitrate reductase activity in leaves is reduced in longan trees treated with soil applications of $\mathrm{KClO}_{3}, \mathrm{NaClO}_{2}$, and bleach (Matsumoto et al., in press).

Reduced nitrogen levels in foliage is hypothesized to be an important factor in determining the receptiveness of the terminals to natural flower induction conditions in lychee, a related species in the family Sapindaceae. Nitrogen levels in excess of $1.85 \%$ results in vegetative flushing, whereas levels of $1.75 \%$ to $1.85 \%$ are conducive to flowering (Menzel et al., 1988). Optimal lychee flowering and fruit set have been correlated with $1.3 \%$ to $1.5 \%$ nitrogen in leaf dry matter in Hawaii, South Africa, India, and Australia (Davenport and Stern, 2005), thus suggesting a possible link between low nitrogen levels and flowering in these Sapindaceae crops.

Hypochlorite enhances flowering in longan similar to potassium chlorate (Sritontip et al., 2005a), and we demonstrate that it can also effectively induce off-season flowering. $\mathrm{NaOCl}$ degradation occurs through two pathways. The first pathway leads to the production of oxygen, whereas the second leads to chlorate formation (Adam and
Gordon, 1999). The incorporation of copper $\left(\mathrm{Cu}^{2+}\right)$ to the bleach solution, an ion that catalyzes both degradation pathways of hypochlorite to chlorate or oxygen (Adam and Gordon, 1999), appeared to induce flowering to the same degree as $\mathrm{KClO}_{3}$ treatment or bleach treatments alone, suggesting chlorate in bleach contributed to the promotion of longan flowering.

Chlorate analysis. To apply equivalent quantities used in field applications of $300 \mathrm{~g} \mathrm{KClO}_{3}$ broadcasted in a 5 - $\mathrm{ft}$ diameter $\left(19.63 \mathrm{ft}^{2}\right)$ under the tree canopy, $26.25 \mathrm{~g}$ $\mathrm{KClO}_{3}$ and $500 \mathrm{~mL}(26.25 \mathrm{~g}$ of $\mathrm{NaOCl}$ ) bleach were applied to potted longan plants in a 17-3/4-inchdiameter $\left(1.72 \mathrm{ft}^{2}\right)$ pot. Leachate collected 4 weeks after treatment contained $173.3 \pm 7.1 \mathrm{mg} \cdot \mathrm{L}^{-1}$ of chlorate from pots treated with $26.25 \mathrm{~g} \mathrm{KClO}_{3}$ and $8.3 \pm 2.3 \mathrm{mg} \cdot \mathrm{L}^{-1}$ of chlorate from pots treated with $0.5 \mathrm{~L}$ bleach. Leachate from control pots contained negligible chlorate (less than $50 \mu \mathrm{g} \cdot \mathrm{L}^{-1}$ ). Presence of chlorate in the leachate from the bleach treatments suggests that hypochlorite was converted to chlorate in the soil or before the application.

Decomposition of bleach to chlorate is also catalyzed by higher temperatures. Nonperishable products

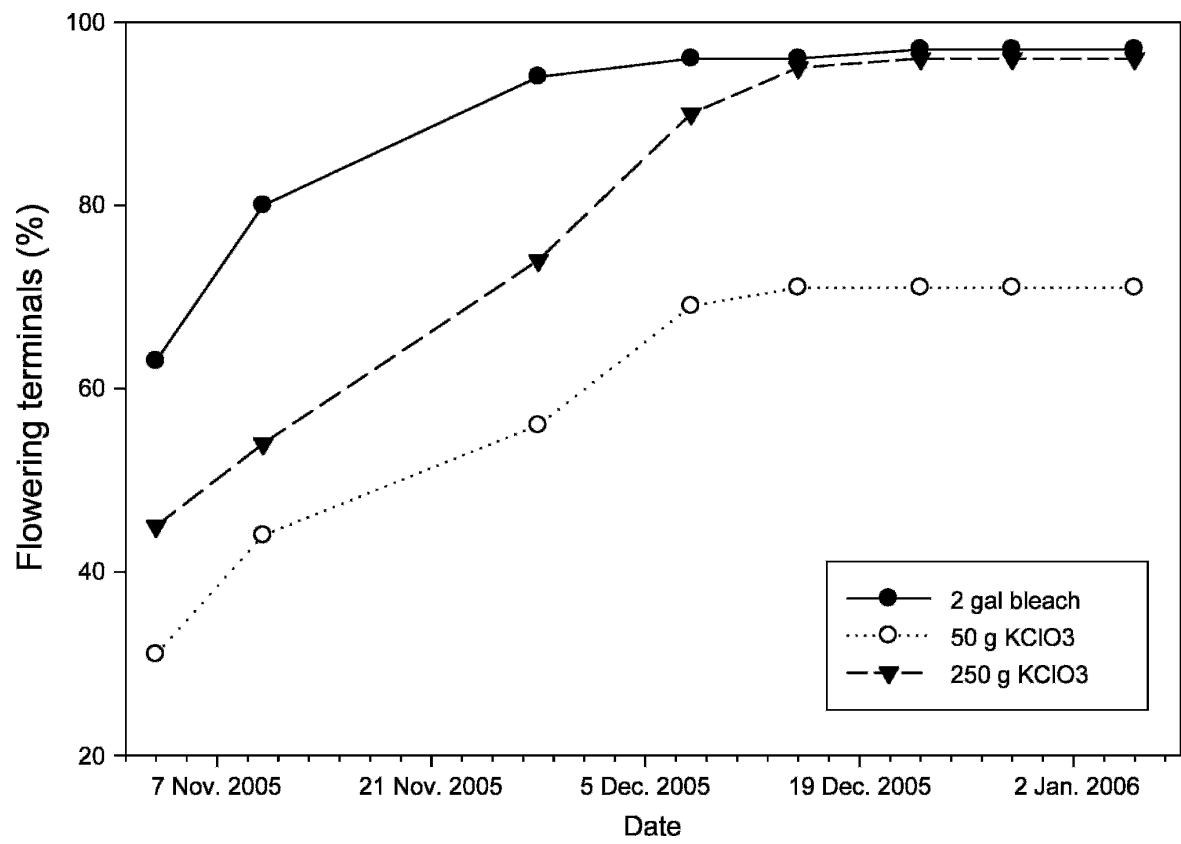

Fig. 1. Percentage of 'Biew Kiew' longan trees with panicles after treatment with $2 \mathrm{gal}(7.6 \mathrm{~L})$ bleach, $50 \mathrm{~g}(1.8 \mathrm{oz})$ potassium chlorate $\left(\mathrm{KClO}_{3}\right)$, or $250 \mathrm{~g}(8.8 \mathrm{oz})$ $\mathrm{KClO}_{3}$ on 16 Sept. 2005. Trees were monitored every 1 to 2 weeks from 3 Nov. 2005 to 6 Jan. 2006. such as bleach may be exposed to elevated temperatures during transportation and storage, which could account for the presence of chlorate in the bleach. Chemical analysis of the bleach resulted in $3.97 \pm 0.65 \mathrm{~g} \cdot \mathrm{L}^{-1}$ sodium chlorate, which is equivalent to 25 to $35 \mathrm{~g}$ of chlorate contained in the 2 gal of bleach applied to the trees.

EXPT. 2. To determine if the amount of chlorate found in bleach could induce longan flowering to the same extent as bleach, 'Biew Kiew' trees in Onomea, Hawaii, were left untreated or treated with $300 \mathrm{~g} \mathrm{KClO}_{3}, 45 \mathrm{~g}$ $\mathrm{KClO}_{3}$, or $2 \mathrm{gal}$ of bleach. The $300-\mathrm{g}$ treatment was previously shown to be effective for inducing flowering in Hawaii (Nagao and Ho-a, 2000), and $45 \mathrm{~g}$ of $\mathrm{KClO}_{3}$ is a high estimate of the amount of chlorate present in $2 \mathrm{gal}$ of bleach applied onto the soil.

Trees treated on 18 May 2005 began flowering 8 weeks after treatment (8 Aug. 2005) and produced new panicles until 16 weeks after treatment. No significant differences in flowering were found between the north and south tree faces for all treatments. Bleach-treated trees flowered at $54.9 \%$ (118 flowering/215 total), which is significantly less $(P=$ 0.048 ) than the $300 \mathrm{~g} \mathrm{KClO}_{3}$ treatments in which $94.0 \% \quad(221$ 
flowering/235 total) of the terminals flowered, but the bleach treatment was not significantly different $(P=$ 0.406 ) compared with $67.9 \%$ (142 flowering/209 total) of the terminals flowering in trees treated with $45 \mathrm{~g}$ $\mathrm{KClO}_{3}$. This suggests that the chlorate in the bleach may be responsible for flower induction in longan.

Trees treated on 16 Sept. 2005 began flowering 7 weeks after treatments (4 Nov. 2005) and actively produced new panicles until 12 weeks (8 Dec. 2005) after treatment (Fig. 1). Flowering on the north and south faces of the trees was not significantly different for $250 \mathrm{~g} \mathrm{KClO}_{3}(P=0.926)$ or 2 gal bleach $(P=0.783)$; however, flowering was significantly different for the $50 \mathrm{~g} \mathrm{KClO}_{3}$ treatment $(P=$ $0.003)$. This difference in the flowering observed between the different faces of the trees treated with $50 \mathrm{~g}$ $\mathrm{KClO}_{3}$ may be attributed to the uneven distribution of chlorate on the soil under the tree canopy. Overall flowering of the trees treated with bleach was $97.1 \%$ (297 flowering/ 306 total terminals), which was not significantly different $(P=0.501)$ than trees treated with $250 \mathrm{~g} \mathrm{KClO}_{3}$ in which $96.4 \%$ (318 flowering/330 total) of the terminals flowered but was significantly greater $(P=0.004)$ than flowering on trees treated with $50 \mathrm{~g} \mathrm{KClO}_{3}$ in which $68.7 \%$ (237 flowering/345 total) of the terminal flowered.

Comparing longan flowering observed in trees treated in May and September, $\mathrm{KClO}_{3}$ at the higher $(250$ or $300 \mathrm{~g}$ ) application rate consistently resulted in over $90 \%$ flowering and the lower $\left(45\right.$ or $50 \mathrm{~g}$ ) $\mathrm{KClO}_{3}$ application rate resulted in $\approx 70 \%$ flowering. Flowering of longan trees treated with bleach varied between the two applications dates with $54.9 \%$ flowering observed after the 18 May 2005 application and $97.1 \%$ flowering observed after the 16 Sept. 2005 application. This increase in flowering may be attributed to the conversion of $\mathrm{NaOCl}$ to chlorate possibly by heat, prolonged storage, or interaction with elements in the soil. We experimentally determined that 25 to $35 \mathrm{~g}$ of chlorate is present in $2 \mathrm{gal}$ of bleach. However, if fully converted to chlorate, 2 gal of bleach would be equivalent to $\approx 397 \mathrm{~g}$ of chlorate, which would result in increased flowering.
In addition to hypochlorite and chlorate, sodium was also added to the soil during the bleach treatment. Soil analyses from trees treated with bleach and control trees at Onomea showed that at 14 weeks after treatment, soil from bleach-treated trees contained $151.3 \pm 36.8 \mathrm{ppm}$ of $\mathrm{Na}^{+}$, whereas soil from untreated control trees contained $37.7 \pm 2.9 \mathrm{ppm}$ of $\mathrm{Na}^{+}$. Soil $\mathrm{pH}$ and salinity were not significantly different in soil samples from bleach-treated and untreated trees and no visible signs of sodium toxicity could be detected. One year after bleach treatment, there was no significant difference between soil samples of bleach-treated trees, $24.4 \pm$ $2.9 \mathrm{ppm}$, and untreated trees, $24.3 \pm$ $4.8 \mathrm{ppm}$, suggesting that sodium did not accumulate in the soil.

Therefore, we conclude that chlorate, chlorite, and bleach are able to induce flowering in longan. Bleach is an effective alternative to potassium chlorate for producing off-season longan fruits. The decomposition of hypochlorite to chlorate in the bleach contributes to the floral induction without sodium accumulation in soil 1 year after application in a high rainfall environment.

\section{Literature cited}

Adam, L.C. and G. Gordon. 1999. Hypochlorite ion decomposition: Effects of temperature, ionic strength and chloride ion. Inorg. Chem. 38:12991304.

Bennett, A.C. and D.R. Shaw. 2000. Effect of preharvest desiccants on weed seed production and viability. Weed Technol. 14:530-538.

Choo, W.K. 2000. Longan production in Asia. Regional Office for Asia and the Pacific (RAP) Publication 2000/20. Food and Agriculture Organization of the United Nations Regional Office for Asia and the Pacific, Bangkok, Thailand.

Crawford, N.M. and B.G. Forde. 2002. Molecular and developmental biology of inorganic nitrogen nutrition. 26 Aug. 2003. <http://www.bioone.org/ archive/1543-8120/46/1/pdf/i15438120-46-1-1.pdf>.

Crawford, N.M. and A.D.M. Glass. 1998. Molecular and physiological aspects of nitrate uptake in plants. Trends Plant Sci. 3:389-395.

Davenport, T.L. and R.A. Stern. 2005. Flowering, p. 87-113. In: C.M. Menzel and G.K. Waite (eds.). The lychee and longan: Botany, production and uses. CABI Publishing, Wallingford, U.K.

Kanaree, W. and T. Pankasemsuk. 2005a. Determination of potassium chlorate residues in 'Do' longan fruit. Acta Hort. 665:249-254.

Kanaree, W. and T. Pankasemsuk. 2005b. Effect of potassium chlorate on fruit quality of 'Do' longan. Acta Hort. 665:281283.

LaBrie, S.T., J.Q. Wilkinson, and N.M. Crawford. 1991. Effect of chlorate treatment on nitrate reductase and nitrate reductase gene expression in Arabidopsis thaliana. Plant Physiol. 97:873879.

Latshaw, W.L. and J.W. Zahnley. 1927. Experiments with sodium chlorate and other chemicals as herbicides for field bindweed. J. Agr. Res. 35:757-767.

Littell, R.C., W.W. Stroup, and R.J. Freund. 2002. SAS for linear models. 4th ed. SAS Institute Inc., Cary, N.C.

Loomis, W.E., E.V. Smith, R. Bissey, and L.E. Arnold. 1933. The absorption and movement of sodium chlorate when used as a herbicide. J. Amer. Soc. Agron. 25:724-739.

Manochai, P., P. Sruamsiri, W. Wiriyaalongkorn, D. Naphrom, M. Hegele, and F. Bangerth. 2005. Year around off season flower induction in longan (Dimocarpus longan, Lour.) trees by $\mathrm{KClO}_{3}$ applications: Potentials and problems. Scientia Hort. 104:379-390.

Matsumoto, T., T. Tsumura, and F. Zee. Exploring the mechanism of potassium chlorate induced flowering in Dimocarpus longan. Acta Hort. (in press).

Menzel, C.M., M.L. Carseldine, and D.R. Simpson. 1988. Crop development and leaf nitrogen in lychee in subtropical Queensland. Austral. J. Expt. Agr. 28: 793-800.

Menzel, C.M., B.J. Watson, and D.R. Simpson. 2002. Longan, p. 259-292. In: T.K. Bose, S.K. Mitra, and S. Sanyal (eds.). Fruits: Tropical and subtropical Vol. 2. Partha Sankar Basu, Calcutta, India.

Meyer, C. and M. Stitt. 2001. Nitrate reduction and signaling, p. 37-59. In: J.F. Morot-Gaudry and P. Lea (eds.). Plant nitrogen. Springer-Verlag, Paris.

Mossler, M.A. and N. Nesheim. 2002. Florida crop/pest management profile: Lychee and longan. An. Cir. (Rosario) CIR1400: March. Coop. Ext. Serv., Univ. of Florida. Inst. of Food and Agr. Sci. Ext., Gainesville. 


\section{Research Reports}

Nagao, M.A. and E.B. Ho-a. 2000. Stimulating longan flowering in Hawaii with potassium chlorate. J. Hawaiian Pacific Agr. 11:23-27.

Neller, J.R. 1930. Effect of chlorates upon the catalase activity of the roots of bindweed. J. Agr. Res. 43:183-189.

Sabhadrabandhu, S. and C. Yapwattanaphun. 2001. Regulation off-season flowering of longan in Thailand. Acta Hort. 558:193-198.

Sritontip, C., Y. Kaosumain, S. Changjaraja, and R. Poruksa. 2005a. Effect of potassium chlorate, sodium hypochlorite and calcium hypochlorite on flowering and some physiological changes in 'Do' longan. Acta Hort. 665:269-273.
Sritontip, C., Y. Khaosumain, S. Changjaraja, and R. Poruksa. 2005b. Effect of potassium chlorate, potassium nitrate, sodium hypochlorite and thiourea on off-season flowering and photosynthesis of 'Do' longan. Acta Hort. 665:291-296.

U.S. Department of Agriculture, National Agriculture Statistics Service and State of Hawaii Department of Agriculture. 2006. Hawaii tropical specialty fruits. 8 Aug. 2006. <http://www.nass.usda.gov/hi/ fruit/tropfrt.pdf $>$.

Wiwatanadate, P., R. Voravong, T. Mahawana, and D. Saraprug. 2001. Health effects in potassium chlorate- exposed longan growers. Internal Medicine J. Thailand 17:94-97.

Yen, C.-R. 2000. From boom to bloom. Agr. Hawaii 3:26-27.

Yen, C.-R., C.-N. Chau, J.-W. Chang, and J.-C. Tzeng. 2001. Effects of chemicals on flowering in longan. J. Chinese Soc. Hort. Sci. 47:195-200.

Zee, F.T.P., H.T. Chan, Jr., and C.-R. Yen. 1998. Lychee, longan, rambutan and pulasan, p. 290-335. In: P. Shaw, H. Chan, S. Nagy, and W.F. Wardowski (eds.). Tropical and subtropical fruits. Agscience, Auburndal, Fla. 